\title{
Factors Influencing Decision-Making for or against Adjuvant and Neoadjuvant Chemotherapy in Postmenopausal Hormone Receptor-Positive Breast Cancer Patients in the EvAluate-TM Study
}

\author{
Paul Gaß ${ }^{1}$ Peter A. Fasching ${ }^{1}$ Tanja Fehm ${ }^{2,3}$ Johann de Waal ${ }^{4}$ Mahdi Rezai ${ }^{5}$ \\ Bernd Baier $^{4}$ Gerold Baake ${ }^{6}$ Hans-Christian Kolberg ${ }^{7}$ Martin Guggenberger ${ }^{8}$ \\ Mathias Warm ${ }^{9,10}$ Nadia Harbeck ${ }^{11}$ Rachel Wuerstlein ${ }^{11}$ Jörg-Uwe Deuker ${ }^{12}$ Peter Dall ${ }^{13}$ \\ Barbara Richter ${ }^{14}$ Grischa Wachsmann ${ }^{15}$ Cosima Brucker ${ }^{16}$ Jan W. Siebers ${ }^{17}$ Nikos Fersis $^{18}$ \\ Thomas Kuhn ${ }^{19}$ Christopher Wolf ${ }^{20}$ Hans-Walter Vollert ${ }^{21}$ Georg-Peter Breitbach ${ }^{22}$ \\ Wolfgang Janni ${ }^{23}$ Robert Landthaler ${ }^{24}$ Andreas Kohls ${ }^{25}$ Daniela Rezek ${ }^{26}$ \\ Thomas Noesselt $^{27}$ Gunnar Fischer ${ }^{28}$ Stephan Henschen ${ }^{29}$ Thomas Praetz $^{30}$ Volker Heyl $^{31}$ \\ Thorsten Kühn ${ }^{32}$ Thomas Krauss ${ }^{33}$ Christoph Thomssen ${ }^{34}$ Andre Hohn ${ }^{35}$ Hans Tesch $^{36}$ \\ Christoph Mundhenke ${ }^{37}$ Alexander Hein ${ }^{1}$ Claudia Rauh ${ }^{1}$ Christian M. Bayer ${ }^{1}$ \\ Adib Jacob ${ }^{38}$ Katja Schmidt ${ }^{38}$ Erik Belleville ${ }^{39}$ Peymann Hadji ${ }^{40}$ Sara Y. Brucker ${ }^{3}$ \\ Matthias W. Beckmann ${ }^{1,42}$ Diethelm Wallwiener ${ }^{3}$ Sherko Kümmel ${ }^{41}$ Christian R. Löhberg ${ }^{1,42}$
}

\footnotetext{
${ }^{1}$ Department of Gynecology and Obstetrics, Comprehensive Cancer Center Erlangen-EMN, Erlangen University Hospital, Friedrich Alexander University of Erlangen-Nuremberg, Erlangen, Germany; ${ }^{2}$ Universitäts-Frauenklinik Düsseldorf, Düsseldorf, Germany; ${ }^{3}$ Department für Frauengesundheit, Universitätsklinikum Tübingen, Eberhard-Karls-Universität Tübingen, Tübingen, Germany; ${ }^{4}$ Frauenklinik im Klinikum Dachau, Dachau, Germany; ${ }^{5}$ Luisenkrankenhaus Düsseldorf, Düsseldorf, Germany; ${ }^{6}$ Onkologische Praxis Pinneberg, Pinneberg, Germany; ${ }^{7}$ Marienhospital Bottrop, Bottrop, Germany; ${ }^{8}$ Klinikum Tuttlingen, Tuttlingen, Germany; ${ }^{9}$ Brustzentrum, Universitäts-Frauenklinik Köln, Cologne, Germany; ${ }^{10}$ Brustzentrum, Klinken der Stadt Köln, Holweide, Cologne, Germany; ${ }^{11}$ Brustzentrum, Klinik und Poliklinik für Frauenheilkunde und Geburtshilfe, Klinikum der Universität München, und CCC, Munich, Germany; ${ }^{12}$ Vinzenzkrankenhaus Hannover, Hanover, Germany; ${ }^{13}$ Frauenklinik, Städtisches Klinikum Lüneburg, Lüneburg, Germany; ${ }^{14}$ Elblandkliniken Meißen-Radebeul, Meißen, Germany; ${ }^{15}$ Kreiskrankenhaus Böblingen, Böblingen, Germany; ${ }^{16}$ Universitätsklinik für Frauenheilkunde, Paracelsus Medizinische Privatuniversität, Nuremberg, Germany; ${ }^{17}$ Frauenklinik der St. Josefsklinik, Offenburg, Germany; ${ }^{18}$ Frauenklinik, Klinikum Bayreuth, Bayreuth, Germany; ${ }^{19} \mathrm{Karl}$-Olga-Krankenhaus, Stuttgart, Germany; ${ }^{20}$ Medizinisches Zentrum Ulm, Ulm, Germany; ${ }^{21}$ Klinikum Friedrichshafen, Friedrichshafen, Germany; ${ }^{22}$ Gynäkologie und Geburtshilfe, Städtisches Klinikum, Neunkirchen, Germany; ${ }^{23}$ Frauenklinik des Universitätsklinikums UIm, Ulm, Germany; ${ }^{24}$ Gynäkologische Praxis in der Kreisklinik Krumbach, Krumbach, Germany; ${ }^{25}$ Evangelisches Krankenhaus Ludwigsfelde-Teltow, Teltow, Germany; ${ }^{26}$ Marien-Hospital, Wesel, Germany; ${ }^{27}$ Klinik für Gynäkologie und Geburtshilfe, Sana Klinikum Hameln-Pyrmont, Hameln, Germany; ${ }^{28}$ Landkreis Mittweida Krankenhaus, Mittweida, Germany; ${ }^{29}$ Johanniter Krankenhaus Genthin Stendal, Stendal, Germany; ${ }^{30}$ Caritas-Krankenhaus, Bad Mergentheim, Germany; ${ }^{31}$ Schwerpunkt-Medizin für minimal invasive Chirurgie, Senologie und Onkologie Mainz, Mainz, Germany; ${ }^{32}$ Frauenklinik, Städtische Kliniken, Esslingen a.N., Germany; ${ }^{33}$ Frauenklinik, Klinikum Passau, Passau, Germany; ${ }^{34}$ Frauenklinik, Martin-Luther-University Halle-Wittenberg, Halle (Saale), Germany; ${ }^{35}$ Städtisches Krankenhaus Kiel, Kiel, Germany; ${ }^{66}$ Onkologie Bethanien, Frankfurt/M., Germany; ${ }^{37}$ Frauenklinik, Universitätsklinikum Schleswig-Holstein Campus Kiel, Kiel, Germany; ${ }^{38}$ Novartis Pharma GmbH, Nuremberg, Germany; ${ }^{39}$ Clin-Sol GmbH, Würzburg, Germany; ${ }^{40}$ Klinik für Gynäkologie und Geburtshilfe, Krankenhaus Nordwest, Frankfurt/M., Germany; ${ }^{41}$ Brustzentrum, Kliniken Essen Mitte, Evangelische Huyssens-Stiftung/Knappschaft GmbH, Essen, Germany; ${ }^{42}$ Frauenklinik, St. Theresien-Krankenhaus, Nuremberg, Germany
}

\section{Keywords}

Oncology · Breast cancer · Postmenopausal .

Chemotherapy · Decision-making

\section{Summary}

Background: Decision-making for or against neoadjuvant or adjuvant chemotherapy in postmenopausal patients with hormone receptor-positive breast cancer does not follow any clear guidelines, and some patients may unnecessarily undergo chemotherapy and be exposed to the associated toxicity. The aim of this study was to identify the patient population for whom this issue may bear relevance. Methods: Patients being treated with letrozole in the prospective multicenter noninterventional EvAluate-

\section{KARGER}

(c) 2016 S. Karger GmbH, Freiburg
Prof. Dr. med. Peter A. Fasching Department of Gynecology and Obstetrics, University Hospital Erlangen Comprehensive Cancer Center Erlangen-EMN, Friedrich-Alexander University Erlangen-Nuremberg Universitätsstraße 21-23, 91054 Erlangen, Germany Peter.Fasching@uk-erlangen.de 
TM study were recruited. The percentage of patients receiving chemotherapy and factors associated with chemotherapy administration were identified. Results: In all, $3,924(37.4 \%)$ patients received chemotherapy before treatment with letrozole. Of these, 293 (20\%) underwent neoadjuvant therapy. Younger age was predictive for both adjuvant and neoadjuvant therapy. Overall, decisions in favor of administering chemotherapy are more likely to be made in patients with a higher body mass index (BMI), and neoadjuvant chemotherapy is administered at a higher rate in women with a lower BMI. Concomitant medication influenced the overall decision-making regarding chemotherapy, irrespective of whether it was given on a neoadjuvant or adjuvant basis. Conclusion: There is an ongoing debate as to whether all of the many patients who receive chemotherapy actually benefit from it. Neoadjuvant chemotherapy is frequently administered in this patient population, and this should encourage further research to resolve current clinical and research issues.

(C) 2016 S. Karger GmbH, Freiburg

\section{Introduction}

Over the last few decades, chemotherapy has become an established treatment for breast cancer patients who have an unfavorable prognosis. In these patients, chemotherapy can improve both disease-free survival and overall survival [1]. Treatment decisions are mainly based on prognosis, which is assessed using patient and tumor characteristics including age, tumor size, nodal status, grading, estrogen receptor (ER) status, progesterone receptor status, and human epidermal growth factor receptor 2 (HER2) status. A few tools are available that can help assess the absolute risk of recurrence on the basis of these factors [2,3]. However, new evidence has recently become available, not only in relation to prognostic groups but also predictive factors, pertaining to the fact that the same form of treatment does not have the same effects in all patients with similar classic patient and tumor characteristics.

A great deal has been learned about chemotherapy from studies on neoadjuvant treatment. The greatest benefit is seen in patients with either triple-negative breast cancer or HER2-positive breast cancer $[4,5]$. The rates of pathological complete response (pCR) are high in these patients, at 30\% for HER2-positive and 34\% for triple-negative breast cancer patients [5]. With these 2 subtypes, complete disappearance of the invasive tumor is associated with a favorable prognosis. However, patients with hormone receptorpositive, HER2-negative tumors have been found to have a pCR rate of $7.4 \%$ if the tumor grade is 1 or 2 , and $16 \%$ if the grade is 3 [5]. In these subtypes, it is not clear whether PCR translates into a favorable prognosis in the same way as it does in patients with HER2-positive or triple-negative breast cancers. Similar data have also been reported from other studies [6]. This suggests that in addition to an unfavorable prognosis, molecular factors may also be potential predictors for the efficacy of chemotherapy and its benefit for breast cancer patients, independently of their prognosis.

These findings have also influenced the treatment guidelines for breast cancer. In 2003, for example, positive lymph nodes were still regarded as an indication for adjuvant chemotherapy [7]. However, the importance attached to lymph node involvement declined over time [8-11], and by 2013, positive lymph node involvement on its own was no longer viewed as an absolute indication for chemotherapy [12]. In contrast, the importance attached to molecular factors among the decision-making criteria for or against chemotherapy has been increasing [7-14]. Particularly in breast cancer patients with hormone receptor-positive tumors it appears to be difficult to assess the potential benefit of cytotoxic therapy [12]. There have been discussions as to whether factors such as Ki-67 and grading may be useful in the decision-making for or against chemotherapy. Patients with low Ki-67 values of under $20 \%$, for example, have been found to have a pCR rate of less than $10 \%$, while patients with $\mathrm{Ki}-67$ values over $35 \%$ have a pCR rate of up to $20 \%$ [6]. However, Ki-67 has not become established as a standard decision-making factor for or against chemotherapy. Recently, several multigene tests, some of which were specifically developed for hormone receptor-positive patients, were shown to identify a subgroup of patients who have such a good prognosis that chemotherapy does not appear to be necessary [15-22]. 2 studies have also prospectively validated the usefulness of these tests in treatment algorithms [21,22]. These studies concluded that chemotherapy may be avoided in patients with a specific genomic profile - a group that represented 20 and 39\%, respectively, of the study populations investigated in the TAILORx (Trial Assigning IndividuaLized Options for Treatment/Rx) and MINDACT (Microarray In Node-negative Disease may Avoid ChemoTherapy) studies $[21,22]$.

Neoadjuvant chemotherapy is an excellent in vivo model for assessing both responsiveness to treatment and the effectiveness of the treatment [4]. Implementing molecular tests and using clinical predictive factors after assessment in the neoadjuvant treatment setting can provide additional information about the predictive capabilities of the tests and factors used. However, neoadjuvant chemotherapy is now only rarely administered in hormone receptor-positive patients.

The following 2 issues are important for planning the optimal incorporation of multigene assays into clinical practice and clinical studies in the neoadjuvant setting: Which hormone receptor-positive breast cancer patients receive systemic therapy at the time of the initial diagnosis? And which patients receive chemotherapy before surgery (neoadjuvant treatment) and after surgery (adjuvant treatment)?

Hence, the aim of this study was to identify patient and tumor characteristics that influence treatment decisions for or against chemotherapy in a group of postmenopausal patients with hormone receptor-positive tumors, who were included in the EvAluate-TM study. A further aim was to identify patient and tumor 
characteristics that determine whether to administer adjuvant or neoadjuvant chemotherapy once a decision in favor of chemotherapy has been made.

\section{Patients and Methods}

\section{Description of the EvAluate-TM Study}

The EvAluate-TM study is a prospective, multicenter, noninterventional, and observational study in which treatment with the aromatase inhibitor letrozole was evaluated in postmenopausal women with hormone receptor-positive breast cancer [23]. To participate, study sites were required to be a part of or associated with a breast cancer center certified by the German Cancer Society (Deutsche Krebsgesellschaft e.V.) and the German Society for Breast Diseases (Deutsche Gesellschaft für Senologie e.V.) [24]. Approval of the study was obtained from the ethical review committee of the Faculty of Medicine at the Friedrich Alexander University of Erlangen-Nuremberg and the relevant ethics committees of all the study centers involved. All patients provided written informed consent after receiving detailed instructions and before inclusion in the noninterventional study.

\section{Patients}

Between April 2008 and April 2009, 5,045 postmenopausal patients at 339 study sites all over Germany were included in the EvAluate-TM study. A total of 5,041 hormone receptor-positive patients were documented in the database (excluding 4 patients). For this analysis, patients were excluded in the following hierarchical order: those with metastatic breast cancer at the time of inclusion $(252$ patients); those in whom antihormonal therapy had started more than 1 year before study entry (238 patients); those with insufficient data quality regarding the start of antihormonal therapy (370 patients); and those who did not complete the patient questionnaire about their satisfaction with the information received (257 patients). The final study population thus consisted of 3,924 postmenopausal patients with primary hormone receptor-positive breast cancer, who started adjuvant therapy with letrozole within 1 year.

\section{Data Acquisition}

Before the start of therapy, data on patient and tumor characteristics, as well as the patients' medical history, were collected and documented in a remote data entry system (using an electronic case report form). Patient information included common epidemiological characteristics, concomitant medication, and diseases.

\section{Statistical Considerations}

Two different binary outcome variables were created. The first (referred to as 'general chemotherapy administration') distinguished between study participants who were treated with adjuvant or neoadjuvant chemotherapy on the one hand, and patients who did not receive adjuvant or neoadjuvant chemotherapy on the other hand. The other binary outcome variable (referred to as 'type of chemotherapy timing') only described patients who were treated with either adjuvant or neoadjuvant chemotherapy, distinguishing between patients who received adjuvant chemotherapy on the one hand, and patients who underwent neoadjuvant chemotherapy on the other hand.

Patient and tumor characteristics were cross-tabulated with these variables and tested for associations using the appropriate chi-squared tests. A logistic regression model was also constructed for each outcome variable as a dependent variable. The model was built using all of the following independent variables: age, body mass index (BMI), number of different co-medications, and number of different co-morbidities, as continuous variables; tumor grade as an ordinal variable; and HER2 status as a binary variable (positive vs. negative). A final model was then built for each model, applying stepwise backward variable selection.

All statistical tests were two-sided, and $\mathrm{p}<0.05$ was regarded as statistically significant. Calculations were carried out using IBM SPSS Statistics for Windows, version 21 (IBM Corporation, Armonk, NY, USA).
Table 1. Patient and tumor characteristics relative to chemotherapy status in all patients

\begin{tabular}{|c|c|c|c|c|}
\hline \multirow[t]{2}{*}{ Characteristics } & \multirow{2}{*}{$\begin{array}{l}\text { Total, } \\
\text { n (\%) }\end{array}$} & \multicolumn{2}{|c|}{ Chemotherapy, n (\%) } & \multirow[t]{2}{*}{$\mathrm{p}$ value } \\
\hline & & no & yes & \\
\hline \multicolumn{5}{|l|}{ Age, years } \\
\hline$<50$ & $93(100)$ & $32(34.4)$ & $61(65.6)$ & $<0.001$ \\
\hline $50-65$ & $1,828(100)$ & $972(53.2)$ & $856(46.8)$ & \\
\hline$>65$ & $1,997(100)$ & $1,449(72.6)$ & $548(27.4)$ & \\
\hline Total, n & 3,918 & 2,453 & 1,465 & \\
\hline \multicolumn{5}{|l|}{ BMI, $\mathrm{kg} / \mathrm{m}^{2}$} \\
\hline$<20$ & $139(100)$ & $89(64.0)$ & $50(36.0)$ & 0.160 \\
\hline $20-25$ & $1,248(100)$ & $801(64.2)$ & 447 (35.8) & \\
\hline $25-30$ & $1,509(100)$ & $937(62.1)$ & $572(37.9)$ & \\
\hline$>30$ & $1,005(100)$ & $617(61.4)$ & $388(38.6)$ & \\
\hline Total, n & 3,901 & 2,444 & 1,457 & \\
\hline \multicolumn{5}{|l|}{ ECOG } \\
\hline 0 or 1 & $3,770(100)$ & $2,356(62.5)$ & $1,414(37.5)$ & 0.353 \\
\hline$>1$ & $151(100)$ & $100(66.2)$ & $51(33.8)$ & \\
\hline Total, n & 3,921 & 2,456 & 1,465 & \\
\hline \multicolumn{5}{|l|}{ Grading } \\
\hline 1 & $586(100)$ & $511(87.2)$ & $75(12.8)$ & $<0.001$ \\
\hline 2 & $2,688(100)$ & $1,711(63.7)$ & $977(36.3)$ & \\
\hline 3 & $623(100)$ & $221(35.5)$ & $402(64.5)$ & \\
\hline Total, n & 3,897 & 2,443 & 1,454 & \\
\hline \multicolumn{5}{|l|}{ HER2 } \\
\hline Negative & $3,402(100)$ & $2,224(65.4)$ & $1,178(34.6)$ & $<0.001$ \\
\hline Positive & $491(100)$ & $208(42.4)$ & $283(57.6)$ & \\
\hline Total, n & 3,893 & 2,432 & 1,461 & \\
\hline \multicolumn{5}{|c|}{ Concomitant medication, $\mathrm{n}$} \\
\hline 0 & $1,685(100)$ & $989(58.7)$ & $696(41.3)$ & $<0.001$ \\
\hline 1 & $605(100)$ & $378(62.5)$ & $227(37.5)$ & \\
\hline 2 & $431(100)$ & $274(63.6)$ & $157(36.4)$ & \\
\hline 3 & $281(100)$ & $165(58.7)$ & $116(41.3)$ & \\
\hline$\geq 4$ & $922(100)$ & $652(70.7)$ & $270(29.3)$ & \\
\hline Total, n & 3,924 & 2,458 & 1,466 & \\
\hline \multicolumn{5}{|c|}{ Concomitant diseases, $\mathrm{n}$} \\
\hline 0 & $1,328(100)$ & $772(58.1)$ & $556(41.9)$ & $<0.001$ \\
\hline 1 & $1,059(100)$ & $647(61.1)$ & $412(38.9)$ & \\
\hline 2 & $745(100)$ & $483(64.8)$ & $262(35.2)$ & \\
\hline 3 & $426(100)$ & $290(68.1)$ & $136(31.9)$ & \\
\hline$\geq 4$ & $366(100)$ & $266(72.7)$ & $100(27.3)$ & \\
\hline Total, $\mathrm{n}$ & 3,924 & 2,458 & 1,466 & \\
\hline
\end{tabular}

BMI = Body mass index ECOG = Eastern Cooperative Oncology Group.

\section{Results}

\section{Patient Characteristics and Univariate Analyses}

A total of 3,924 postmenopausal patients with hormone receptor-positive breast cancer who were included in the EvAluate-TM study participated in this analysis. Of these, 1,466 (37.4\%) patients received chemotherapy, either in the neoadjuvant or the adjuvant setting. The mean age of the patients enrolled was $65.0 \pm 8.3$ years, 
Table 2. Logistic regression analysis (final model) with significant patient and tumor characteristics for predicting the general choice of chemotherapy

\begin{tabular}{lllr}
\hline Characteristics & OR $^{\mathrm{a}}$ & $95 \% \mathrm{CI}$ & p value \\
\hline Age $^{\mathrm{b}}$ & 0.92 & $0.91-0.93$ & $<0.001$ \\
BMI $^{\mathrm{b}}$ & 1.02 & $1.01-1.04$ & 0.002 \\
Grading $^{\mathrm{b}}$ & 3.76 & $3.20-4.36$ & $<0.001$ \\
HER2 & & & \\
$\quad$ Negative & $1.00^{\mathrm{c}}$ & & \\
$\quad$ Positive & 2.00 & $1.61-2.49$ & $<0.001$ \\
Concomitant medication & 0.97 & $0.95-0.99$ & 0.004 \\
\hline
\end{tabular}

${ }^{\mathrm{a}}$ Adjusted.

boR per unit.

${ }^{\mathrm{c}}$ Reference.

$\mathrm{OR}=$ Odds ratio; $\mathrm{CI}=$ confidence interval; $\mathrm{BMI}=$ body mass index

and their mean BMI was $27.4 \pm 5.2 \mathrm{~kg} / \mathrm{m}^{2}$. All other tumor characteristics were within the expected ranges and frequencies and are shown in table 1. As tumor size and nodal status was only available for patients who were not treated neoadjuvantly, data for this group of patients is provided in supplementary table 1 (available at www.karger.com/?DOI=452468).

\section{General Chemotherapy Use}

Patients who received chemotherapy were more than 4 years younger than those who did not $(62.1 \pm 7.3$ years vs. $66.7 \pm 8.5$ years; $\mathrm{p}<0.001$ ). Although $46.8 \%$ of all patients aged $50-65$ years received chemotherapy, only $27.4 \%$ of women aged over 65 were treated with chemotherapy (table 1). There did not appear to be any differences in BMI $(27.3 \pm 5.1$ vs. $27.6 \pm 5.3 ; \mathrm{p}=0.076)$. The molecular parameters of grading and HER 2 were clearly associated with chemotherapy administration. Although $64.5 \%$ of all patients with grade 3 tumors received chemotherapy, only $12.8 \%$ of those with grade 1 tumors had cytotoxic treatment. HER2-positive patients received chemotherapy in $57.6 \%$ of cases and HER2-negative patients in $34.6 \%$. All further associations with patient and tumor characteristics are shown in table 1.

In the multivariate model, age, BMI, tumor grade, HER2 status, and number of concomitant medications remained in the model predicting general chemotherapy administration. Younger age, higher BMI, higher tumor grade, positive HER2 status, and low comedication use were associated with chemotherapy administration (table 2). We repeated the analysis after exclusion of neoadjuvantly treated patients, this time including tumor stage. Tumor stage and nodal status additionally remained in the final model and were associated with the decision for adjuvant chemotherapy (supplementary table 2 , available at $w w w$. karger.com/?DOI=452468).

\section{Neoadjuvant Chemotherapy Administration}

Among the group of patients treated with chemotherapy ( $\mathrm{n}=$ 1,466), 20\% received neoadjuvant chemotherapy ( $n=293 ; 7.5 \%$ of the complete cohort). The only 2 variables that indicated an association with neoadjuvant rather than adjuvant chemotherapy administration were age and BMI. Patients who received neoadjuvant treatment were approximately 2.5 years younger than those who received adjuvant treatment $(60.1 \pm 7.5$ years vs. $62.6 \pm 7.2$ years $)$. The mean BMI of women who received neoadjuvant treatment was $26.8 \pm 4.8$, compared to $27.8 \pm 5.4$ among those who received adjuvant treatment. Neoadjuvant therapy was thus used in $13.5 \%$ of all women who were older than 65 years and in $23.4 \%$ of those aged 50-65 years (table 3 ). The neoadjuvant chemotherapy rates ranged from $24 \%$ in women with a $\mathrm{BMI}<20 \mathrm{~kg} / \mathrm{m}^{2}$ to $17.3 \%$ in women with a BMI $>30 \mathrm{~kg} / \mathrm{m}^{2}$.

Age and BMI were the only 2 variables that persisted in the selection process used in the logistic regression model. They remained as independent predictive factors for the administration of neoadjuvant chemotherapy (table 4 ).

\section{Discussion}

The study showed that approximately $37 \%$ of all postmenopausal women with hormone receptor-positive breast cancer received adjuvant or neoadjuvant chemotherapy. Of these, $20 \%$ received neoadjuvant treatment. Age, BMI, tumor grade, and HER2 were clearly correlated with chemotherapy administration; age and BMI were clearly correlated with the administration of neoadjuvant chemotherapy.

When the percentage of chemotherapy utilization in the EvAluate-TM study is compared with that in large adjuvant aromatase inhibitor studies, the rate of chemotherapy in this patient population was higher than the rates reported in the ATAC (Arimidex, Tamoxifen Alone or in Combination) and Breast International Group 1-98 (BIG 1-98) studies (21 and 25\%, respectively) [25, 26]. However, this figure lies in the range of previous chemotherapy rates (32\%) reported in the Intergroup Exemestane Study 031 (IES031) [27]. This might be due to the fact that initial aromatase inhibitor therapy was not regarded as standard for a long time after first publications of improved disease-free survival but not overall survival for this treatment approach $[25,26]$. An overall survival benefit was only reported later, in 2011, and only for 1 substance, within a specifically applied statistical analysis [28]. This might be one reason for the higher percentage of women with an unfavorable prognosis in the EvAluate-TM study. On the other hand, during the recruitment period for the large adjuvant aromatase inhibitor studies, trastuzumab had not yet been approved, leading to a lower percentage of women receiving chemotherapy among HER2positive patients.

Interestingly, only $57.6 \%$ of the HER2-positive women were treated with adjuvant chemotherapy - meaning that only $57.6 \%$ of the patients could have been treated with trastuzumab which was approved before the start of recruitment for the EvAluate-TM study. This closely approximates the percentage of women who were reported to have an indication for trastuzumab (52.7\%) in a study in the Netherlands [29]. While $78.1 \%$ of the women in the Netherlands study received trastuzumab, about $15 \%$ of these women had no indication for trastuzumab [29]. The figure of $57.6 \%$ in the present study thus appears plausible. 
Table 3. Patient and tumor characteristics relative to neoadjuvant or adjuvant chemotherapy status in the group of patients receiving chemotherapy

\begin{tabular}{|c|c|c|c|c|}
\hline \multirow[t]{2}{*}{ Characteristics } & \multirow{2}{*}{$\begin{array}{l}\text { Total, } \\
\text { n (\%) }\end{array}$} & \multicolumn{2}{|c|}{ Chemotherapy, n (\%) } & \multirow[t]{2}{*}{$\mathrm{p}$ value } \\
\hline & & neoadjuvant & adjuvant & \\
\hline \multicolumn{5}{|l|}{ Age, years } \\
\hline$<50$ & $61(100)$ & $19(31.1)$ & $42(68.9)$ & $<0.001$ \\
\hline $50-65$ & $856(100)$ & $200(23.4)$ & $656(76.6)$ & \\
\hline$>65$ & $548(100)$ & $74(13.5)$ & $474(86.5)$ & \\
\hline Total, n & 1,465 & 293 & 1,172 & \\
\hline \multicolumn{5}{|l|}{ BMI, $\mathrm{kg} / \mathrm{m}^{2}$} \\
\hline$<20$ & $50(100)$ & $12(24.0)$ & $38(76.0)$ & 0.027 \\
\hline $20-25$ & $447(100)$ & $103(23.0)$ & $344(77.0)$ & \\
\hline $25-30$ & $572(100)$ & $109(19.1)$ & $463(80.9)$ & \\
\hline$>30$ & $388(100)$ & $67(17.3)$ & $321(82.7)$ & \\
\hline Total, n & 1,457 & 292 & 1,166 & \\
\hline \multicolumn{5}{|l|}{ ECOG } \\
\hline 0 or 1 & $1,414(100)$ & $281(19.9)$ & $1,133(80.1)$ & 0.521 \\
\hline$>1$ & $51(100)$ & $12(23.5)$ & $39(76.5)$ & \\
\hline Total, n & 1,465 & 2,456 & 1,465 & \\
\hline \multicolumn{5}{|l|}{ Grading } \\
\hline 1 & $75(100)$ & $12(16.0)$ & $63(84.0)$ & 0.611 \\
\hline 2 & $977(100)$ & $199(20.4)$ & $778(79.6)$ & \\
\hline 3 & $402(100)$ & $77(19.2)$ & $325(80.8)$ & \\
\hline Total, n & 1,454 & 288 & 1,166 & \\
\hline \multicolumn{5}{|l|}{ HER2 } \\
\hline Negative & $1,178(100)$ & 235 (19.9) & $943(80.1)$ & 0.942 \\
\hline Positive & $283(100)$ & $57(20.1)$ & $226(79.9)$ & \\
\hline Total, n & 1,461 & 292 & 1,169 & \\
\hline \multicolumn{5}{|c|}{ Concomitant medication, $\mathrm{n}$} \\
\hline 0 & $696(100)$ & $139(20.0)$ & $557(80.0)$ & 0.438 \\
\hline 1 & $227(100)$ & $48(21.1)$ & $179(78.9)$ & \\
\hline 2 & $157(100)$ & $33(21.0)$ & $124(79.0)$ & \\
\hline 3 & $116(100)$ & $31(26.7)$ & $85(73.3)$ & \\
\hline$\geq 4$ & $270(100)$ & $42(15.6)$ & $228(84.4)$ & \\
\hline Total, $\mathrm{n}$ & 1,466 & 293 & 1,171 & \\
\hline \multicolumn{5}{|c|}{ Concomitant diseases, $\mathrm{n}$} \\
\hline 0 & $556(100)$ & $118(21.2)$ & $438(78.8)$ & 0.074 \\
\hline 1 & $412(100)$ & $91(22.1)$ & $321(77.9)$ & \\
\hline 2 & $262(100)$ & $47(17.9)$ & $215(82.1)$ & \\
\hline 3 & $136(100)$ & $18(13.2)$ & $118(86.8)$ & \\
\hline$\geq 4$ & $100(100)$ & $19(19.0)$ & $81(81.0)$ & \\
\hline Total, $\mathrm{n}$ & 1,466 & 293 & $1,173(100)$ & \\
\hline
\end{tabular}

$\mathrm{BMI}=$ Body mass index $\mathrm{ECOG}=$ Eastern Cooperative Oncology Group.
Table 4. Logistic regression analysis (final model) with significant patient and tumor characteristics for predicting neoadjuvant or adjuvant chemotherapy

\begin{tabular}{lllr}
\hline Characteristics & OR $^{\mathrm{a}}$ & $95 \% \mathrm{CI}$ & p value \\
\hline Age $^{\mathrm{b}}$ & 0.96 & $0.94-0.94$ & $<0.001$ \\
BMI $^{\mathrm{b}}$ & 0.97 & $0.94-0.99$ & 0.017 \\
\hline
\end{tabular}

${ }^{\text {a Adjusted. }}$

boR per unit.

$\mathrm{OR}=$ Odds ratio $\mathrm{CI}=$ confidence interval $; \mathrm{BMI}=$ body mass index.
The rate of chemotherapy administration may have increased over time among patients with hormone receptor-positive breast cancer [30]. However, information about subgroups of women who do not benefit from chemotherapy is now available, and there is hence a strong need to identify subgroups in whom toxic chemotherapy can be avoided.

Recent reports from prospective randomized trials investigating treatment algorithms using multigene prognostic tests [21, 22] appear to have supplied the information needed to allow these tests to be incorporated systematically into healthcare so that unnecessary chemotherapy can be avoided among patients with breast cancer. 
There have been several reports on the use of multigene assays in clinical practice and on the way in which they can alter treatment decisions for or against chemotherapy [30-34]. The results have so far been inconsistent, but this may change on the basis of 2 recently published randomized studies $[21,22]$ suggesting that chemotherapy rates can be reduced by 20 and $29 \%$, respectively. On the basis of the data from the EvAluate-TM study, there may be around 50,000 patients with hormone receptor-positive breast cancer in Germany per year $[35,36]$ - implying an opportunity to reduce chemotherapy by about 4,000-8,000 patients per year.

With regard to neoadjuvant chemotherapy, age and BMI were the only factors that were predictive for the administration of neoadjuvant chemotherapy in the group of patients who received chemotherapy. Rates of neoadjuvant chemotherapy vary widely within institutions and between countries [37]. In a study in the United States, the rate of utilization of neoadjuvant chemotherapy was reported to be around 3\% [37]. At 7.5\%, this figure was more than twice as high in the EvAluate-TM study. In both studies, the main predictive factor identified was age. In the EvAluate-TM study, information about tumor size and nodal status was not available at the time of chemotherapy decision-making, while these 2 variables were also identified as predictors for neoadjuvant chemotherapy administration in the study by Onitilo et al. [37]. Interestingly, the physicians and patients in the present study did not appear to regard co-morbidities and co-medication as reasons for not performing neoadjuvant chemotherapy.

This study has several strengths, but also some limitations. It needs to be borne in mind that all of the women included in the study had been selected for treatment with letrozole as an initial therapy. At the time of recruitment for the study, scientific and clinical discussions were in progress regarding which patients should receive which therapy in relation to tamoxifen, aromatase inhibitors, and sequence of administration [38-40]. At that time, some held the view that an initial aromatase inhibitor might only be necessary in breast cancer patients who had an increased risk of recurrence, whereas women with a lower risk of recurrence could be treated with tamoxifen followed by an aromatase inhibitor after 2-3 years. The study population included in the EvAluate-TM study might therefore involve some bias in relation to this topic namely, selecting for a group of patients with a greater risk of recurrence and thus including a higher percentage of women who received chemotherapy. Another limitation is the fact that tumor size and nodal status had to be excluded from the analysis since tumor size was not recorded as the clinical but only the pathological tumor size. Tumor size, at the time of decision-making, was thus not available in the $20 \%$ of patients who received neoadjuvant treatment. The same applies to nodal status. In addition, the study was conducted in 2008 and 2009. Although it was already known at that time that some tumor subtypes, such as tumors with a high level of ER expression, benefit less from chemotherapy [9], it can be assumed that this information had not yet been incorporated into common practice in relation to treatment decision-making. One strength of this study is the large sample size and its prospec- tive nature. It is one of the largest studies concerned with treatment management for postmenopausal patients with hormone receptorpositive breast cancer. Another strength is the broad distribution and number of the participating study sites. The study thus presents an average picture of treatment management in this field throughout Germany at the time when it was conducted.

In conclusion, this study provides data on the use of neoadjuvant and adjuvant chemotherapy in postmenopausal patients with hormone receptor-positive early breast cancer. This represents the population of breast cancer patients in whom the potential for avoiding unnecessary chemotherapy is under discussion. The EvAluate-TM study also provides evidence that neoadjuvant chemotherapy is commonly performed in this patient population, and this should encourage future molecular research in neoadjuvant chemotherapy trials in this group of patients.

\section{Online Supplementary Tables}

Supplementary Table 1. Patient and tumor characteristics relative to adjuvant chemotherapy (excluding patients with neoadjuvant chemotherapy) status in all patients

Supplementary Table 2. Logistic regression analysis (final model) with significant patient and tumor characteristics for predicting the general choice of adjuvant chemotherapy

To access the online supplementary tables, please refer to www.karger. com/?DOI=452468.

\section{Acknowledgment}

We would like to express our thanks to the participating study centers and to all of the patients who participated in the study. All analyses were conducted independently of Novartis. The manuscript was also prepared independently of Novartis. Data sovereignty remains with the principal medical investigators.

\section{Funding}

PAF received honoraria from Amgen, Celgene, Roche, Pfizer, Genomic Health, Novartis, and Teva. H-CK received fees from Amgen, Novartis, Teva, Pfizer, Carl Zeiss Meditec, GSK, and Roche. MG received fees from Novartis, AstraZeneca, and Roche. NH received fees from Novartis. RW received fees and research funding from Novartis. NF received fees from Novartis and research funding from Novartis. WJ received fees and research funding from Novartis. TK received fees from Novartis. HT received fees from Novartis. CR received fees from Novartis. CMB received fees from Roche. SK received fees from Roche, Celgene, and Novartis. The research was financially supported by Novartis, which enabled us to carry out this study.

\section{Disclosure Statement}

PAF has carried out research for Novartis and Amgen. KS and AJ are employees of Novartis Pharma. EB has carried out research for Novartis, Celgene, BMS, and Roche. MWB is a member of the EvAluate-TM study group. All of the other authors declare that they have no conflicts of interest. 


\section{References}

1 Peto R, Davies C, Godwin J, Gray R, Pan HC, Clarke M, Cutter D, Darby S, McGale P, Taylor C, Wang YC, Bergh J, Di Leo A, Albain K, Swain S, Piccart M, Pritchard K; Early Breast Cancer Trialists' Collaborative Group: Comparisons between different polychemotherapy regimens for early breast cancer: meta-analyses of long-term outcome among 100,000 women in 123 randomised trials. Lancet 2012;379:432-444.

2 Wishart GC, Bajdik CD, Dicks E, Provenzano E, Schmidt MK, Sherman M, Greenberg DC, Green AR, Gelmon KA, Kosma VM, Olson JE, Beckmann MW, Winqvist R, Cross SS, Severi G, Huntsman D, Pylkas K, Ellis I, Nielsen TO, Giles G, Blomqvist C, Fasching PA, Couch FJ, Rakha E, Foulkes WD, Blows FM, Begin LR, van't Veer LJ, Southey M, Nevanlinna H, Mannermaa A, Cox A, Cheang M, Baglietto L, Caldas C, Garcia-Closas M, Pharoah PD: Predict plus: development and validation of a prognostic model for early breast cancer that includes HER2. Br J Cancer 2012;107:800807.

3 Ravdin PM, Siminoff LA, Davis GJ, Mercer MB, Hewlett J, Gerson N, Parker HL: Computer program to assist in making decisions about adjuvant therapy for women with early breast cancer. J Clin Oncol 2001;19: 980-991.

4 Von Minckwitz G, Untch M, Blohmer JU, Costa SD, Eidtmann H, Fasching PA, Gerber B, Eiermann W, Hilfrich J, Huober J, Jackisch C, Kaufmann M, Konecny GE, Denkert C, Nekljudova V, Mehta K, Loibl S: Definition and impact of pathologic complete response on prognosis after neoadjuvant chemotherapy in various intrinsic breast cancer subtypes. J Clin Oncol 2012;30:1796-1804

5 Cortazar P, Zhang L, Untch M, Mehta K, Costantino JP, Wolmark N, Bonnefoi H, Cameron D, Gianni L, Valagussa P, Swain SM, Prowell T, Loibl S, Wickerham DL, Bogaerts J, Baselga J, Perou C, Blumenthal G, Blohmer J, Mamounas EP, Bergh J, Semiglazov V, Justice R, Eidtmann H, Paik S, Piccart M, Sridhara R, Fasching PA, Slaets L, Tang S, Gerber B, Geyer CE Jr, Pazdur R, Ditsch N, Rastogi P, Eiermann W, von Minckwitz G: Pathological complete response and longterm clinical benefit in breast cancer: the CTNeoBC pooled analysis. Lancet 2014;384:164-172.

6 Von Minckwitz G, Eidtmann H, Loibl S, Blohmer JU, Costa SD, Fasching PA, Kreienberg R, Hilfrich J, Gerber B, Hanusch C, Fehm T, Strumberg D, Solbach C, Nekljudova V, Untch M: Integrating bevacizumab, everolimus, and lapatinib into current neoadjuvant chemotherapy regimen for primary breast cancer. Safety results of the GeparQuinto trial. Ann Oncol 2011;22:301-306.

7 Goldhirsch A, Wood WC, Gelber RD, Coates AS, Thurlimann B, Senn HJ: Meeting highlights: updated international expert consensus on the primary therapy of early breast cancer. J Clin Oncol 2003;21:3357-3365.

8 Goldhirsch A, Wood WC, Coates AS, Gelber RD, Thurlimann B, Senn HJ; Panel members: Strategies for subtypes - dealing with the diversity of breast cancer: highlights of the St. Gallen International Expert Consensus on the primary therapy of early breast cancer 2011. Ann Oncol 2011;22:1736-1747.

9 Goldhirsch A, Ingle JN, Gelber RD, Coates AS, Thurlimann B, Senn HJ; Panel members: Thresholds for therapies: highlights of the St. Gallen International Expert Consensus on the primary therapy of early breast cancer 2009. Ann Oncol 2009;20:1319-1329.

10 Goldhirsch A, Wood WC, Gelber RD, Coates AS, Thurlimann B, Senn HJ; 10th St. Gallen conference: Progress and promise: highlights of the international expert consensus on the primary therapy of early breast cancer 2007. Ann Oncol 2007;18:1133-1144.
11 Goldhirsch A, Glick JH, Gelber RD, Coates AS, Thurlimann B, Senn HJ, Panel members: Meeting highlights: international expert consensus on the primary therapy of early breast cancer 2005. Ann Oncol 2005;16:15691583.

12 Goldhirsch A, Winer EP, Coates AS, Gelber RD, Piccart-Gebhart M, Thurlimann B, Senn HJ, Panel members: Personalizing the treatment of women with early breast cancer: highlights of the St. Gallen International Expert Consensus on the primary therapy of early breast cancer 2013. Ann Oncol 2013;24:2206-2223.

13 Goldhirsch A, Glick JH, Gelber RD, Senn HJ: Meeting highlights: international consensus panel on the treatment of primary breast cancer. J Natl Cancer Inst 1998; 90:1601-1608.

14 Goldhirsch A, Glick JH, Gelber RD, Coates AS, Senn HJ: Meeting highlights: international consensus panel on the treatment of primary breast cancer. Seventh international conference on adjuvant therapy of primary breast cancer. J Clin Oncol 2001;19:3817-3827.

15 Perou CM, Sorlie T, Eisen MB, van de Rijn M, Jeffrey SS, Rees CA, Pollack JR, Ross DT, Johnsen H, Akslen LA, Fluge O, Pergamenschikov A, Williams C, Zhu SX, Lonning PE, Borresen-Dale AL, Brown PO, Botstein D: Molecular portraits of human breast tumours. Nature 2000;406:747-752.

16 Sorlie T, Perou CM, Tibshirani R, Aas T, Geisler S, Johnsen H, Hastie T, Eisen MB, van de Rijn M, Jeffrey SS, Thorsen T, Quist H, Matese JC, Brown PO, Botstein D, Lonning PE, Borresen-Dale AL: Gene expression patterns of breast carcinomas distinguish tumor subclasses with clinical implications. Proc Natl Acad Sci U S A 2001;98:10869-10874.

17 Van de Vijver MJ, He YD, van't Veer LJ, Dai H, Hart AA, Voskuil DW, Schreiber GJ, Peterse JL, Roberts C, Marton MJ, Parrish M, Atsma D, Witteveen A, Glas A, Delahaye L, van der Velde T, Bartelink H, Rodenhuis S, Rutgers ET, Friend SH, Bernards R: A gene-expression signature as a predictor of survival in breast cancer. N Engl J Med 2002;347:1999-2009.

18 Van 't Veer LJ, Dai H, van de Vijver MJ, He YD, Hart AA, Mao M, Peterse HL, van der Kooy K, Marton MJ, Witteveen AT, Schreiber GJ, Kerkhoven RM, Roberts C, Linsley PS, Bernards R, Friend SH: Gene expression profiling predicts clinical outcome of breast cancer. Nature 2002;415:530-536.

19 Paik S, Shak S, Tang G, Kim C, Baker J, Cronin M, Baehner FL, Walker MG, Watson D, Park T, Hiller W, Fisher ER, Wickerham DL, Bryant J, Wolmark N: A multigene assay to predict recurrence of tamoxifentreated, node-negative breast cancer. N Engl J Med 2004;351:2817-2826.

20 Filipits M, Rudas M, Jakesz R, Dubsky P, Fitzal F, Singer CF, Dietze O, Greil R, Jelen A, Sevelda P, Freibauer C, Muller V, Janicke F, Schmidt M, Kolbl H, Rody A, Kaufmann M, Schroth W, Brauch H, Schwab M, Fritz P, Weber KE, Feder IS, Hennig G, Kronenwett R, Gehrmann M, Gnant M; EP Investigators: A new molecular predictor of distant recurrence in ER-positive, HER2-negative breast cancer adds independent information to conventional clinical risk factors. Clin Cancer Res 2011;17:6012-6020.

21 Sparano JA, Gray RJ, Makower DF, Pritchard KI, Albain KS, Hayes DF, Geyer CE Jr, Dees EC, Perez EA, Olson JA Jr, Zujewski J, Lively T, Badve SS, Saphner TJ, Wagner LI, Whelan TJ, Ellis MJ, Paik S, Wood WC, Ravdin P, Keane MM, Gomez Moreno HL, Reddy PS, Goggins TF, Mayer IA, Brufsky AM, Toppmeyer DL, Kaklamani VG, Atkins JN, Berenberg JL, Sledge GW: Prospective validation of a 21-gene expression assay in breast cancer. N Engl J Med 2015;373:2005-2014.
22 Cardoso F, van 't Veer LJ, Bogaerts J, Slaets L, Viale G, Delaloge S, Pierga JY, Brain E, Causeret S, DeLorenzi M, Glas AM, Golfinopoulos V, Goulioti T, Knox S, Matos E, Meulemans B, Neijenhuis PA, Nitz U, Passalacqua R, Ravdin P, Rubio IT, Saghatchian M, Smilde TJ, Sotiriou C, Stork L, Straehle C, Thomas G, Thompson AM, van der Hoeven JM, Vuylsteke P, Bernards R, Tryfonidis K, Rutgers E, Piccart M; MINDACT Investigators: 70-gene signature as an aid to treatment decisions in early-stage breast cancer. N Engl J Med 2016; 375:717-729.

23 Fasching PA, Fehm T, Kellner S, de Waal J, Rezai M, Baier B, Baake G, Kolberg H-C, Guggenberger M, Warm M, Harbeck N, Würstlein R, Deuker J-U, Dall P, Richter B, Wachsmann G, Brucker C, Siebers JW, Fersis N, Kuhn T, Wolf C, Vollert H-W, Breitbach G-P, Janni W, Landthaler R, Kohls A, Rezek D, Noesslet T, Fischer G, Henschen S, Praetz T, Heyl V, Kühn T, Krauß T, Thomssen C, Kümmel S, Hohn A, Tesch $\mathrm{H}$, Mundhenke C, Hein A, Rauh C, Bayer CM, Jacob A, Schmidt K, Belleville E, Hadji P, Wallwiener D, Grischke E-M, Beckmann MW, Brucker SY: Evaluation of therapy management and patient compliance in postmenopausal patients with hormone receptor-positive breast cancer receiving letrozole treatment: the EvaluateTM study. Geburtshilfe Frauenheilkd 2014;74: 1137-1143.

24 Beckmann MW, Brucker C, Hanf V, Rauh C, Bani MR, Knob S, Petsch S, Schick S, Fasching PA, Hartmann A, Lux MP, Haberle L: Quality assured health care in certified breast centers and improvement of the prognosis of breast cancer patients. Onkologie 2011;34:362-367.

25 Baum M, Budzar AU, Cuzick J, Forbes J, Houghton JH, Klijn JG, Sahmoud T, Group AT: Anastrozole alone or in combination with tamoxifen versus tamoxifen alone for adjuvant treatment of postmenopausal women with early breast cancer: first results of the ATAC randomised trial. Lancet 2002;359:2131-2139.

26 Thurlimann B, Keshaviah A, Coates AS, Mouridsen H, Mauriac L, Forbes JF, Paridaens R, Castiglione-Gertsch M, Gelber RD, Rabaglio M, Smith I, Wardley A, Price KN, Goldhirsch A; Breast International Group (BIG) 1-98 Collaborative Group: A comparison of letrozole and tamoxifen in postmenopausal women with early breast cancer. N Engl J Med 2005;353:2747-2757.

27 Coombes RC, Hall E, Gibson LJ, Paridaens R, Jassem J, Delozier T, Jones SE, Alvarez I, Bertelli G, Ortmann O, Coates AS, Bajetta E, Dodwell D, Coleman RE, Fallowfield LJ, Mickiewicz E, Andersen J, Lonning PE, Cocconi G, Stewart A, Stuart N, Snowdon CF, Carpentieri M, Massimini G, Bliss JM, van de Velde C; Intergroup Exemestane Study: A randomized trial of exemestane after two to three years of tamoxifen therapy in postmenopausal women with primary breast cancer. N Engl J Med 2004;350:1081-1092.

28 Colleoni M, Giobbie-Hurder A, Regan MM, Thurlimann B, Mouridsen H, Mauriac L, Forbes JF, Paridaens R, Lang I, Smith I, Chirgwin J, Pienkowski T, Wardley A, Price KN, Gelber RD, Coates AS, Goldhirsch A: Analyses adjusting for selective crossover show improved overall survival with adjuvant letrozole compared with tamoxifen in the BIG 1-98 study. J Clin Oncol 2011;29:1117-1124.

29 Seferina SC, Lobbezoo DJ, de Boer M, Dercksen MW, van den Berkmortel F, van Kampen RJ, van de Wouw AJ, de Vries B, Joore MA, Peer PG, Voogd AC, TjanHeijnen VC: Real-life use and effectiveness of adjuvant trastuzumab in early breast cancer patients: a study of the Southeast Netherlands Breast Cancer Consortium. Oncologist 2015;20:856-863. 
30 Kuijer A, Drukker CA, Elias SG, Smorenburg CH, Th Rutgers EJ, Siesling S, van Dalen T: Changes over time in the impact of gene-expression profiles on the administration of adjuvant chemotherapy in estrogen receptor positive early stage breast cancer patients: a nationwide study. Int J Cancer 2016;139:769-775.

31 Exner R, Bago-Horvath Z, Bartsch R, Mittlboeck M, Retel VP, Fitzal F, Rudas M, Singer C, Pfeiler G, Gnant M, Jakesz R, Dubsky P: The multigene signature MammaPrint impacts on multidisciplinary team decisions in ER+, HER2- early breast cancer. Br J Cancer 2014;111:837-842.

32 Ademuyiwa FO, Miller A, O'Connor T, Edge SB Thorat MA, Sledge GW, Levine E, Badve S: The effects of oncotype DX recurrence scores on chemotherapy utilization in a multi-institutional breast cancer cohort. Breast Cancer Res Treat 2011;126:797-802

33 Geffen DB, Abu-Ghanem S, Sion-Vardy N, Braunstein R, Tokar M, Ariad S, Delgado B, Bayme M, Koretz M: The impact of the 21-gene recurrence score assay on decision making about adjuvant chemotherapy in early-stage estrogen-receptor-positive breast cancer in an oncology practice with a unified treatment policy. Ann Oncol 2011;22:2381-2386.
34 Albanell J, Svedman C, Gligorov J, Holt SD, Bertelli G, Blohmer JU, Rouzier R, Lluch A, Eiermann W: Pooled analysis of prospective European studies assessing the impact of using the 21-gene recurrence score assay on clinical decision making in women with oestrogen receptor-positive, human epidermal growth factor receptor 2-negative early-stage breast cancer. Eur J Cancer 2016;66:104-113.

35 Rusner C, Bandemer-Greulich U, Engel J, Stegmaier C, Zawinell A, Holleczek B, Katalinic A, Kuss O, SchmidtPokrzywniak A, Schubert-Fritschle G, Tillack A, Stang A: Population-based hormone receptor-specific incidence trends of breast cancer in Germany. Maturitas 2012;73:152-157.

36 Eisemann N, Waldmann A, Katalinic A: Epidemiology of breast cancer - current figures and trends. Geburtshilfe Frauenheilkd 2013;73:130-135.
37 Onitilo AA, Onesti JK, Single RM, Engel JM, James TA, Aiello Bowles EJ, Spencer Feigelson H, Barney T, McCahill LE: Utilization of neoadjuvant chemotherapy varies in the treatment of women with invasive breast cancer. PloS One 2013;8:e84535.

38 Ellis MJ, Rigden CE: Initial versus sequential adjuvant aromatase inhibitor therapy: a review of the current data. Curr Med Res Opin 2006;22:2479-2487.

39 Tusquets Trias de Bes I, Tormo SS, Mestres JA: Start strong or switch? Adjuvant endocrine strategies for postmenopausal women with hormone-sensitive breast cancer. Biomed Pharmacother 2009;63:1-10.

40 Chlebowski RT: Optimizing aromatase inhibitor integration into initial treatment strategies in postmenopausal women with hormone-receptor-positive early breast cancer. Breast Cancer Res Treat 2008;112(suppl 1):25-34. 